\title{
SPECIES DIVERSITY OF SEGETAL COMMUNITIES IN TUBER CROPS AND IN WINTER AND SPRING CEREALS
}

\author{
Zofia Rzymowska, Maria Kugowska, Janina Skrzyczyńska \\ Department of Agricultural Ecology of the Siedlce University of Natural Sciences and Humanities \\ B. Prusa 14, 08-110 Siedlce, Poland \\ e-mail: zrzymowska@wp.pl
}

Received: 15.03.2013

\section{Abstract}

The work presents the results of studies on the diversity of weed communities in tuber crops as well as in winter and spring cereals under similar climatic and soil conditions. We examined overall species abundance in the groups analysed, the average species number per relevé, as well as weed cover of the study area. Additionally, species composition, number of individual species and their biomass were determined. Dominant species in each crop group were distinguished. Species diversity was determined based on the following ecological indices: the Shannon-Wiener index of biodiversity $H^{\prime}$ and Simpson's index of dominance $C$. The indices were computed on the biomass and number-of-species basis. The objective of the work was to compare the structure and diversity of weed communities in the crops studied. The communities analysed differed in all the characteristics examined. Differences were found between biodiversity and dominance indices calculated for individual crop groups, but their significance depended on the method applied to calculate the indices.

Key words: weeds, number of species, fresh matter, dry matter, different crop groups, ecological indices

\section{INTRODUCTION}

Production intensification limits biodiversity through changes in the proportions of crops cultivated, increased mineral fertilisation and pesticide application as well as simplifications of agrotechnology [1-3]. Weeds constitute an important element of agricultural ecosystems because they not only compete with crop plants but are also a component of trophic chains influencing the occurrence of many fauna and microflora species [2, 4, 5]. Many factors, such as habitat, climate and agrotechnology, influence the species composition of segetal communities. One of the most important agrotechnological factors which regulate the occurren- ce of weeds is the crop plant, as it requires a number of cultural practices [6]. The species diversity of an agricultural ecosystem depends on the abundance and number of species $[5,7-10]$. There are more and more works in agricultural literature which evaluate communities using biological indices. These works usually focus on cereals or one crop species and examine the effects of various factors over years.

The aim of this work was to compare the structure and diversity of weed communities in various crop groups using selected ecological indices.

\section{MATERIALS AND METOHODS}

Observations of weed infestation were made in the years 2011-2012. An experiment was set up in the fields of private agricultural holdings in one locality in the Siedlecka Upland. The experiment was conducted under conditions typical of the majority of farms in the study area where weeds in tuber and root crops are controlled by means of mechanical methods, whereas the application of chemicals is limited. Herbicides are applied in winter cereals predominantly to control loose silky bent, while in spring cereals they are used to reduce the number of dicotyledonous weeds, which often results in grass compensation. In order to carry out the experiment, fields with the same soil conditions were selected to grow 3 groups of crops: winter cereals, spring cereals, and tuber crops.

Thirty fields were randomly selected in each crop group in order to analyse biodiversity. A phytosociological relevé was taken from each uniform plant patch, and then a quadrat (quantitative-gravimetric) method was applied to two replications of samples which were then used to obtain a composite sample from $1 \mathrm{~m}^{2}$. A $0.5 \mathrm{~m}^{2}$ quadrat was used to determine the 
species composition and number of individual species and then fresh and dry matter. Weed infestation was evaluated in the period of optimal community development: in late June and July in cereals and in mid- and late August in potatoes.

The material obtained was used to analyse the structure and species abundance of weed communities occurring in the examined crop groups. The following were determined: total species number in individual crops, average species number per relevé, average species number per $1 \mathrm{~m}^{2}$, and fresh and dry matter per $1 \mathrm{~m}^{2}$. Moreover, dominant species in individual crop groups were distinguished - they were the species belonging to class $\mathrm{V}$ or IV of phytosociological constancy and/or the cover index $\geq 100$.

Biodiversity was assessed using the following ecological indices: the Shannon-Wiener index of biodiversity $\left(H^{\prime}\right)$ and Simpson's index of dominance $(C)$ [11]. The values of the indices for each crop plant were statistically analysed. As the data were not normally distributed, they were transformed using the following formula: $y=\ln x$.
A one-way analysis of variance was used to investigate differences between the indices calculated based on the species number, dry matter and fresh matter depending on the crop group. Significance of differences between means was checked using Tukey's test at $\mathrm{p} \leq 0.05$.

\section{RESULTS}

The crop groups studied had different structure and species composition. The biodiversity analysis of the communities examined based on species number demonstrated that the greatest total and average numbers of species per relevé were found in tuber crops ( 83 species and an average of 17.5 species per relevé) and the lowest in spring cereals (56 species and an average of 12.3 species per relevé) (Table 1). The estimated weed cover and fresh and dry matter per $1 \mathrm{~m}^{2}$ were the highest in the tuber crop. Winter cereals were characterised by the highest average number of species and number of individuals of a given species per $1 \mathrm{~m}^{2}$. Spring cereals had the lowest average values of these parameters.

Table 1

Description of selected characteristics of weed communities that infest the crops studied

\begin{tabular}{|c|c|c|c|c|c|c|}
\hline \multirow{2}{*}{ Parameter studied } & \multicolumn{2}{|c|}{ Winter cereals } & \multicolumn{2}{|c|}{ Spring cereals } & \multicolumn{2}{|c|}{ Tuber crops } \\
\hline & $\min -\max$ & mean & $\min -\max$ & mean & $\min -\max$ & mean \\
\hline Number of species in relevés & $10-27$ & 16.4 & $5-28$ & 12.3 & $7-34$ & 17.5 \\
\hline Total cover of weeds $(\%)$ & $10-70$ & 25.8 & $5-40$ & 16.7 & $10-100$ & 45.7 \\
\hline Weed species number per $\mathrm{m}^{-2}$ & $5-25$ & 12.3 & $4-19$ & 8.8 & $4-21$ & 9.4 \\
\hline $\begin{array}{l}\text { Number of weed individuals, } \\
\text { plants per } \mathrm{m}^{-2}\end{array}$ & $92-1066$ & 393.5 & $34-868$ & 259.9 & $34-226$ & 102.1 \\
\hline Weed biomass, $\mathrm{g}$ per $\mathrm{m}^{-2}$ & $41.6-516.6$ & 178.1 & $41.64-490.9$ & 150.1 & $120.5-1586$ & 802.5 \\
\hline Dry matter, g per $\mathrm{m}^{-2}$ & $12.36-329.1$ & 66.5 & $6.96-169.6$ & 46.2 & $26.2-395.8$ & 192.9 \\
\hline Total number of species & \multicolumn{2}{|c|}{73} & \multicolumn{2}{|c|}{56} & \multicolumn{2}{|c|}{83} \\
\hline
\end{tabular}

The highest number of dominant species (12 species) was for the tuber crops. The species included: Echinochloa crus-galli, Setaria pumila, Chenopodium album, Galinsoga parviflora, G. ciliata, Viola arvensis, Anthemis arvensis and Polygonum lapathifolium subsp. lapathifolium. In turn, in winter crops there were 11 dominant species, including: Anthoxanthum aristatum, Centaurea cyanus, Apera spica-venti, Viola arvensis, Anthemis arvensis and others. In spring crops there were 9 dominant species, that is: Setaria pumila, Matricaria maritima subsp. inodora, Avena fatua, Galium aparine, Echinochloa crus-galli, Viola arvensis, Agrostis stolonifera and Avena strigosa. Species such as: Setaria pumila, Matricaria maritima subsp. inodora, Anthemis arvensis and Viola arvensis, were classified as dominant in all the crop groups.
The analysis of species origin showed a higher proportion of archeophytes in cereals compared with tuber crops (Fig. 1). The share of apophytes in tuber crops and winter cereals was at the same level, whereas in spring cereals it was lower. By contrast, the share of epecophytes was three times as high as in winter cereals; in tuber crops they constituted less than $10 \%$.

The highest and lowest average values of the biodiversity index were obtained when it was calculated, respectively, on the number-of-individuals and dry matter basis. The opposite tendency was observed for the dominance index, but for winter cereals and tuber crops only. The highest values of the dominance index were also obtained for spring cereals when calculated on the number-of-individuals basis. The value of the biodiversity index was the lowest for spring cereals 
irrespective of the calculation method applied. The index calculated based on the number-of-individuals criterion had the highest average value for winter cereals and tuber crops and significantly differed from the average index for spring cereals. By contrast, when calculated on the fresh- and dry-matter basis for tuber crops, it did not differ significantly from spring cereals. Opposite relationships were observed when the dominance index was the case. Its average values were the highest for spring cereals irrespective of the calculation method and they did not differ from the remaining crop groups. Yet, the significance of differences depended on the calculation method applied. The biodiversity index determined on the number-of-individual basis did not differ between winter cereals and tuber crops. By contrast, when calculated on the fresh- and dry-matter basis, it did not differ between spring cereals and tuber crops.

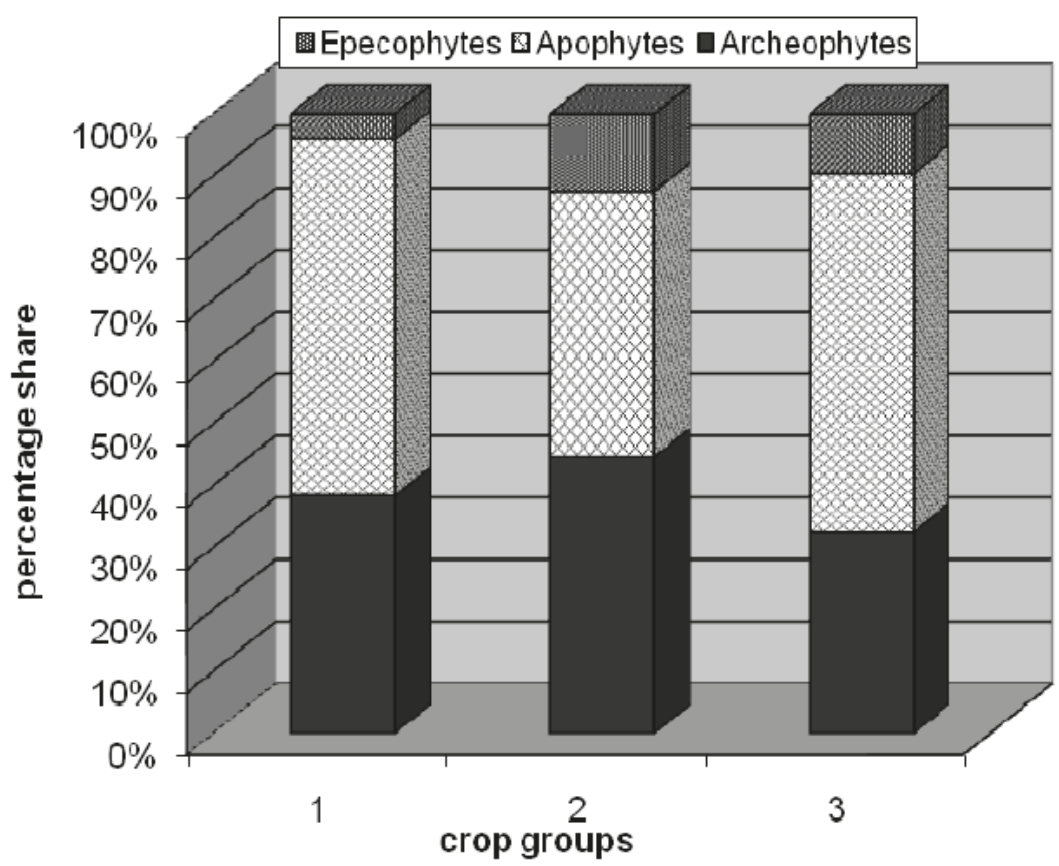

Fig. 1. Percentage share of geographical-historical species groups in weed communities in the crops studied. 1 - winter cereals; 2 - spring cereals; 3 - tuber crops

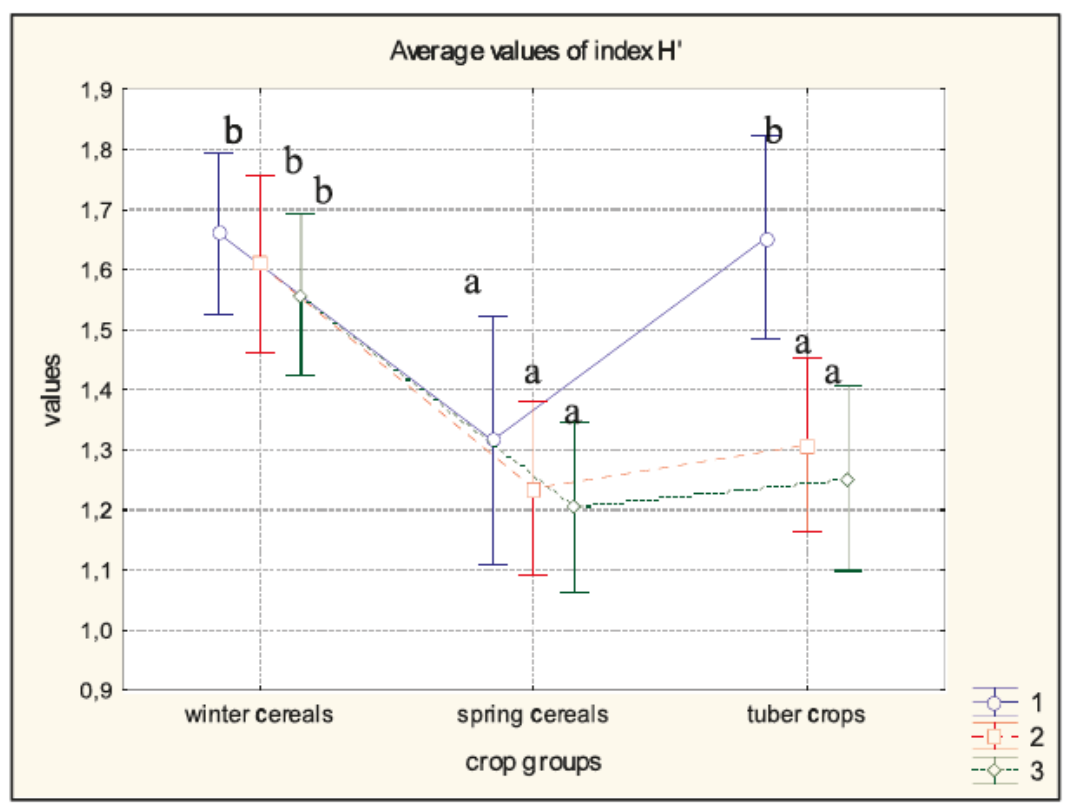

Fig. 2. Average values of Shannon-Wiener's diversity index $H^{\prime}$ in crop groups according to the calculation method 1 - density; 2 - fresh matter; 3 - dry matter; ab - significant at 0.05 level 


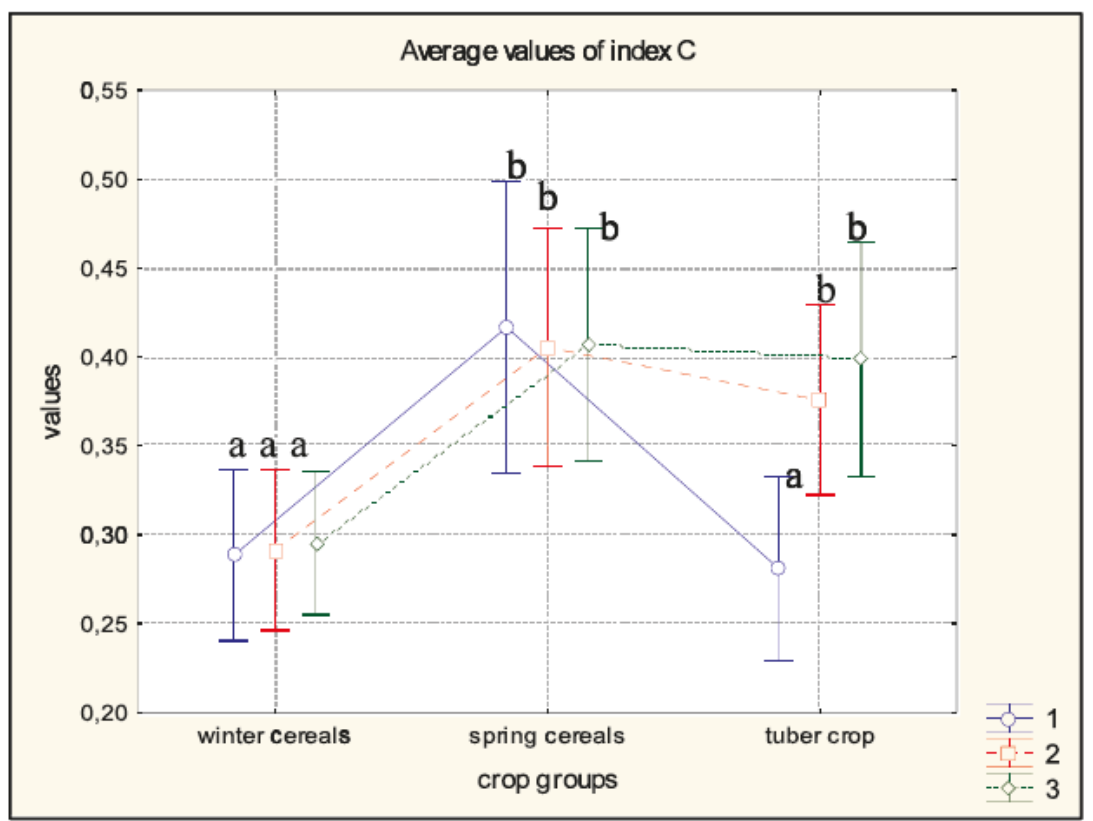

Fig. 3. Average values of Simpson's domination index $C$ in crop groups according to the calculation method. 1 - density; 2 - fresh matter; 3 - dry matter; ab - significant at 0.05 leve

Table 2

Dominant species of weed communities

\begin{tabular}{|c|c|c|c|c|c|c|}
\hline \multirow{2}{*}{ Species } & \multicolumn{2}{|c|}{ Winter cereals } & \multicolumn{2}{|c|}{ Spring cereals } & \multicolumn{2}{|c|}{ Tuber crops } \\
\hline & $\mathrm{S}$ & $\mathrm{D}$ & $S$ & $\mathrm{D}$ & $\mathrm{S}$ & $\mathrm{D}$ \\
\hline Agrostis stolonifera & $\mathrm{V}$ & 147 & IV & 113 & & \\
\hline Anthemis arvensis & III & 200 & IV & 67 & IV & 210 \\
\hline Anthoxanthum aristatum & II & 467 & \multicolumn{2}{|c|}{$*$} & - & - \\
\hline Apera spica-venti & $\mathrm{V}$ & 347 & \multicolumn{2}{|c|}{$*$} & - & - \\
\hline Centaurea cyanus & $\mathrm{V}$ & 372 & \multicolumn{2}{|c|}{$*$} & \multicolumn{2}{|c|}{ * } \\
\hline Matricaria maritima subsp. inodora & IV & 100 & III & 195 & III & 118 \\
\hline Scleranthus annuus & II & 108 & \multicolumn{2}{|c|}{ * } & \multicolumn{2}{|c|}{$*$} \\
\hline Setaria pumila & IV & 130 & $\mathrm{~V}$ & 487 & $\mathrm{~V}$ & 647 \\
\hline Vicia angustifolia & IV & 107 & \multicolumn{2}{|c|}{$*$} & \multicolumn{2}{|c|}{$*$} \\
\hline Viola arvensis & $\mathrm{V}$ & 267 & $\mathrm{~V}$ & 100 & IV & 240 \\
\hline Elymus repens & IV & 68 & \multicolumn{2}{|c|}{$*$} & \multicolumn{2}{|c|}{$*$} \\
\hline Avena fatua & - & - & III & 200 & \multicolumn{2}{|c|}{$*$} \\
\hline Avena strigosa & - & - & I & 102 & & \\
\hline Echinochloa crus-galli & \multicolumn{2}{|c|}{ * } & III & 137 & IV & 707 \\
\hline Galium aparine & \multicolumn{2}{|c|}{$*$} & II & 137 & \multicolumn{2}{|c|}{$*$} \\
\hline Galeopsis tetrahit & \multicolumn{2}{|c|}{ * } & \multicolumn{2}{|c|}{$*$} & II & 118 \\
\hline Rumex acetosella & \multicolumn{2}{|c|}{$*$} & \multicolumn{2}{|c|}{$*$} & III & 145 \\
\hline Chenopodium album & \multicolumn{2}{|c|}{ * } & \multicolumn{2}{|c|}{$*$} & $\mathrm{~V}$ & 403 \\
\hline Polygonum lapathifolium subsp. lapathifolium & \multicolumn{2}{|c|}{$*$} & \multicolumn{2}{|c|}{$*$} & IV & 197 \\
\hline Digitaria ischaemum & \multicolumn{2}{|c|}{$*$} & \multicolumn{2}{|c|}{$*$} & II & 190 \\
\hline Galinsoga parviflora & - & - & \multicolumn{2}{|c|}{$*$} & II & 340 \\
\hline Galinsoga ciliata & - & - & \multicolumn{2}{|c|}{$*$} & II & 227 \\
\hline
\end{tabular}

$\mathrm{S}$ - constancy, D - cover coefficient, * - species occurred with ground cover $<100$ 


\section{DISCUSSION}

Phytocenoses of cultivated fields are influenced by human activities such as cultural practices [6]. The successful existence of weeds in agroecosystems is mainly due to their diversity and enormous abilities to produce seeds [12]. The structure of a developing biocoenosis is determined by the crop plant selected for cultivation, because it requires certain cultural practices [13-15]. Also, the sowing date, crop plant density and fertilisation markedly influence the biocoenosis as they modify the habitat conditions. Meteorological conditions during the growing season are also very important [9], in addition to many other less recognized factors. According to K r a w c z y k [16], there are many factors which influence the biodiversity of segetal flora so it is difficult to unambiguously determine any trends in changes in weed infestation. The aforementioned factors, in addition to many others, cause the quantitative and qualitative diversity of phytocoenoses developing in different crop groups. The relationships discussed affect the structure and biodiversity of communities establishing in different crops, which is also supported by the study results presented in this paper. Individual crop groups had a different floristic composition of phytocenoses, the total number of species and the average number of species per relevé. The most floristically abundant communities were observed in winter cereals. They were usually the most stable phytocenoses with the smallest share of epecophytes. Differences observed in the cover or biomass amount, in addition to soil fertility, are influenced by cultural practices, weed control methods in particular $[17,18]$. The conditions of the experiment in question, in which weed control methods typical of the study area were used, had a marked influence on the composition and structure of the communities analysed. The weed control methods applied substantially increased weed infestation of tuber crops and winter cereals. In spring cereals, this was reflected in the composition of dominant species which included such expansive species as Avena fatua, Setaria pumila, and Echinochloa crus-galli. No Raphanus raphanistrum plants were found, so it was effectively controlled by herbicides. It indicates that there was an influence of the chemicals applied on the composition and biodiversity of phytocenoses. The application of herbicides removing dicotyledonous weeds leads to the compensation of monocotyledonous species $[19,20]$. In the experiment in question, it was difficult to make comparisons of the effects of chemicals on the indices calculated because in most fields similar practices had been applied in a given crop group. The literature contains conflicting evidence on the effect of herbicides on community species diversity. Stupnicka-Rodzynkiewicz et al. [17] have reported that there was an influence of herbicides on weed number but not diversity. Similarly R o la and R o la [21] have pointed out that crop plants are accompanied by relatively species-stable communities which are only slightly modified by agriculture intensification, including herbicides. Reverse relations were observed by We s o ło w s ka-Janczare k et al. [22], Trzcińs ka-T a cik [7], and Feledyn- S z ewczyk [5].

The value of ecological indices of the crop groups examined depended on the calculation method. In all the study groups, the biodiversity index had the highest values when calculated based on the number of species; by contrast, they were the lowest for the dry-matter approach. Opposite relationships were reported by J a strzę bska et al. [18] in their studies on horse bean. They found higher values of the biodiversity index when the biomass-based approach was applied. In our study, the values of the dominance index for winter cereals were similar irrespective of how it was estimated, whereas for tuber crops the values of this index were the lowest when computed on the number-of-individuals basis. Opposite, though less distinct, relationships were observed for spring crops. The variation in the indices calculated based on the number of individuals and biomass is the result of differences in the size of individuals. Even rare weeds often have large biomass, which affects the value of the indices, the dominance index in particular. From the point of view of agriculture, the domination of biomass of one or a few species is much more dangerous than a great number of small seedlings of other species [18].

In the experiment discussed, the biodiversity indices were lower and dominance was higher in spring versus winter cereals. It is to a great extent the effect of the application of herbicides which leads to the compensation of some species. Moreover, spring cereals usually follow potatoes in rotation and then, when conditions are favourable, diaspores accumulated in the soil after tuber crops are released. Their amount is particularly large when no chemicals have been applied and there has been massive secondary weed infestation. The ambiguous results of a study on the effect of the previous crop [18], cultivation methods and herbicides applied indicate that the problem is complex and there are a few simultaneous effects, of meteorological factors in particular, which are mentioned by many researchers $[9,23]$. Differences in the community composition and structure result from specific agrotechnological conditions associated with the crop plant. Although it is widely believed that the differences between communities in winter cereals, spring cereals and tuber crops are disappearing [20,24], there is a group of weeds specific to one group of crops, for example winter cereals (Nigella arvensis, Agrostemma githago, Veronica triphyllos and others), which are rarely 
found in other crops. In turn, communities developing in spring cereals are intermediate between associations characteristic for winter cereals and tuber crops due to a shorter growing season and better thermal and light conditions [25-30], which affects the occurrence in these crops of thermophilic species accompanying tuber crops. To sum up, both production intensification and the land use structure negatively influence the biodiversity of segetal communities.

\section{CONCLUSIONS}

1. The communities studied in individual crop groups had a different composition and structure, as indicated by an analysis of many characteristics that determine them.

2. Community biodiversity in individual crop groups was different and the significance of the differences depended on the method of index calculation.

3. Intensification of production and simplifications in land use structure both limit the biodiversity.

\section{Acknowledgements}

Research supported by the Ministry of Science and Higher Education of Poland as part of the statutory activities of the Department of Agricultural Ecology, Siedlce University of Natural Sciences and Humanities.

\section{Author's contributions}

The following declarations about authors' contributions to the research have been made: concept of the study: ZR, MŁ; field work: ZR, MŁ; data analysis: $\mathrm{ZR}$, MŁ; writing of the manuscript: ZR, MŁ, JS.

\section{REFERENCES}

1. Skrzyczyńska J., Rzymowska Z., Pawlonka Z. Wpływ systemu gospodarowania na agrocenozy Wysoczyzny Siedleckiej. / Effect of farming system on agrophytocenoses in the Siedlce Upland. Fragm. Agron. 2007; 24(4): 176-183. (in Polish)

2. Dobrzański A., Adamczewski K. Wpływ walki z chwastami na bioróżnorodność agrofitocenozy. / The influence of weed control on agrophytocenosis biodiversity. Prog. Plant Prot. / Post. Ochr. Roślin. 2009; 49(3): 982-995. (in Polish)

3. Storkey J., Meyer S., Still K.S., Leuschner C. The impact of agricultural intensification and land-use change on the European arable flora. Proc. R. Soc. B. 2012; 279: 1421-1429. http://dx.doi.org/10.1098/rspb.2011.1686

4. Marshall E.J.P., Brown V.K., Boatman N.D., Lutman P.J.W., Squire G.R., Ward L.K. The role of weeds in supporting biological diversity within crop fields. Weed Res. 2003; 43: 77-89. http://dx.doi.org/ 10.1046/j.1365-3180.2003.00326.x

5. Feledyn-Szewczyk B. Zmiany bioróżnorodności flory segetalnej w systemie ekologicznym w latach 19962007. / The changes of biodiversity of weed flora in organic system in the years 1996-2007. J. Res. Appl. Agric. Eng. 2008; 53(3): 63-68. (in Polish)

6. Duer I., Feledyn-Szewczyk B. Skład gatunkowy i biomasa chwastów występujących w pszenicy ozimej uprawianej w różnych systemach produkcji oraz ich udział w pobieraniu składników mineralnych z gleby. / Species composition and biomass of weeds in winter wheat cultivated under different crop production systems and their contribution to the uptake of mineral components from the soil. Pam. Puł. 2003; 134: 65-77. (in Polish)

7. Trz c ińs k a - Ta c i k H. Znaczenie różnorodności gatunkowej chwastów segetalnych. / Importance of field weeds species diversity. Pam. Puł. 2003; 134: 253-262. (in Polish)

8. Stupnicka-Rodzynkiewicz E., Stępnik K., Dąbkowska T., Łabza T. Różnorodność zbiorowisk chwastów w uprawach zbóż w Beskidach. / Diversity of cereal crops weed communities in the Beskidy Mountains. Fragm. Agron. 2004; 21(4): 45-53. (in Polish)

9. Wanic M., Jastrzębska M., Kostrzewska M.K., Nowicki J. Analiza zbiorowisk chwastów za pomocą wskaźników ekologicznych / Analysis of weeds communities using selected biological indicators. Acta Agrobot. 2005; 58(1): 227-242. http://dx.doi.org/10.5586/aa. 2005.026 (in Polish)

10. Skrzyczyńska J., Ługowska M. Dominacja gatunków i bioróżnorodność zbiorowisk agrocenoz ziemniaka Doliny Środkowej Wisły. / Species domination and biodiversity in weed communities of agrocenoses of the Middle Vistula Valley. Zesz. Probl. Post. Nauk Rol. 2008; 530: 105-115. (in Polish)

11. Topham P.B., Law s on H.M. Measurement of weed species diversity in crop /weed competition studies/. Weed Res. 1982; 22: 285-293.

12. Dekker J. Weed diversity and weed management. Weed Sci. 1997; 45: 357-363.

13. Malicki L., Podstawka-Chmielewska E., $\mathrm{K} w$ iecińska E. Fitocenoza łanu niektórych roślin na rędzinie w warunkach zróżnicowanej uprawy roli. / The phytocoenosis of some crops on rendzina soil under different tillage conditions. Fragm. Agron. 2000; 17(2): 30-44. (in Polish)

14. Jędruszczak M., Antoszek R. Sposoby uprawy roli a bioróżnorodność zbiorowisk chwastów w monokulturze pszenicy ozimej. / Tillage systems and biodiversity of weed communities in winter wheat monoculture. Acta Sci. Pol. Agricultura. 2004; 3(2): 47-59. (in Polish)

15. Jastrzębska M., Orzech K., Kostrzewska M.K., Wanic M., Nowicki J. Różnorodność chwastów w łanach roślin przy różnych sposobach uprawy roli. / Weed diversity in the plant canopies with different methods of soil cultivation. Fragm. Agron. 2006; 23(4): 103-118. (in Polish) 
16. K r awc z yk R. Kierunki zmian zachwaszczenia - szanse i zagrożenia. / Trends in changes of weed infestation - hope and risk. Prog. Plant Prot. /Post. Ochr. Roślin. 2005; 45(1): 233-241. (in Polish)

17. Stupnicka-Rodzynkiewicz E., Stępnik K., Lepiarczyk A. Wpływ zmianowania, sposobu uprawy roli i herbicydów na bioróżnorodność zbiorowisk chwastów. / Effect of the crop rotation, tillage method and herbicides on the biodiversity of weed communities. Acta Sci. Pol., Agricultura. 2004; 3(2): 235-245. (in Polish)

18. Jastrzębska M., Bogucka B., Hruszka M. Następstwo roślin i proekologiczne sposoby regulacji zachwaszczenia a bioróżnorodność chwastów w bobiku. / Crop sequence and environment-friendly weed control methods versus weed biodiversity in faba bean fields. Acta Agrophys. 2007; 10(2): 357-371. (in Polish)

19. Hołdyński Cz. Flora segetalna, zróżnicowanie florystyczno-ekologiczne i przemiany szaty roślinnej pól uprawnych w aktualnych warunkach agroekologicznych Żuław Wiślanych. / Segetal flora, floristic and ecological differentiation and changes in the plant cover of cultivated fields in current agroecological conditions of Żuławy Wiślane. Acta Acad. Agricult. Tech. Olst. 403, Agricultura. 1991; 51: 1-51. (in Polish)

20. Siciński J. T. Agrofitocenozy dorzecza środkowej Warty i Bzury - stan, dynamika i zagrożenia. / Agrophytocenoses of the middle Warta and Bzura river basin - the present state, dynamics and threats. Wyd. UŁ, Rozpr. 2003: 1-69. (in Polish)

21. Rola J., Rola H. Pozytywne i negatywne aspekty stosowania herbicydów w uprawach rolniczych w latach 19502000. / Positive and negative aspects of herbicide application in agriculture crops in Poland (1950-2000). Prog. Plant Prot. /Post. Ochr. Roślin. 2001; 40(1): 93-100. (in Polish)

22. Wesołowska-Janczarek M., Kubik-Komar M., Jędruszczak M. Zastosowanie współczynników bioróżnorodności do badania wpływu sposobu uprawy i dawki herbicydu na zbiorowisko chwastów. / Application of diversity indices to study the influence of tillage system and doses of herbicides on weed community. Polskie Towarzystwo Biometryczne, Colloquium Biometryczne. 2000; 30: 333-344. (in Polish)

23. Wanic M., Jastrzębska M., Kostrzewska M.K., Nowicki J. Zjawisko dominacji gatunkowej w fitocenozie owsa. / Species domination in oats phytocenosis and its yield. Acta Agrobot. 2006;59(2): 303-321. http://dx.doi. org/10.5586/aa.2006.085 (in Polish)

24. Sk r z y c z yńs k a J. Zachwaszczenie upraw Wysoczyzny Siedleckiej na tle warunków glebowych. Cz. II. Zmiany w zachwaszczeniu pól uprawnych. / Weed infestation of the cultivated fields of Siedlecka Upland against a background of soil conditions. Rocz. Nauk Rol. Ser. A. 1999; 114(1-2): 153-163. (in Polish)

25. Korna ś J. Zespoły roślinne Jury Krakowskiej. Cz. I. Zespoły pól uprawnych. / Plant associations of the Kraków Jurassic area. Part 1. Associations of cultivated fields. Acta Soc. Bot. Pol. 1950; 20(2): 361-438. (in Polish)
26. Siciński J.T. Uwagi o aspektach sezonowych zbiorowisk zbożowych. / Remarks on the seasonal aspects of plant communities on cereal crop fields. Acta. Agrobot. 1984; 37(21): 91-112. (in Polish)

27. Kozak M. Zbiorowiska segetalne gminy Rudniki (województwo opolskie). / Segetal communities in the Rudniki municipality area (Opole Voivodship). Fragm. Flor. Geobot. Polonica. 2002; 9: 219-272. (in Polish)

28. Węg r z y nek B. Roślinność segetalna Wyżyny Śląskiej. Cz. 3. Zbiorowiska chwastów upraw zbożowych ze związku Caucalidion lappulae. Zubożałe zbiorowiska chwastów zbóż ozimych i jarych. / The segetal vegetation of the Silesian Upland. Part 3. Cereal weed communities of Caucalidiom lappulae alliance. Rump weed communities of winter and spring crop. Acta Biol. Sil. 2003; 37(54): 120-150. (in Polish)

29. Skrajna T., Skrzyczyńska J. Zbiorowiska przejściowe i kadłubowe występujące w łanach zbóż Wysoczyzny Kałuszyńskiej. / Temporary and impoverished communities occurring in cereal fields of the Kałuszyńska Upland. Acta Sci. Pol. Biologia. 2006; 5(1-2): 59-72. (in Polish)

30. Rzymowska Z., Skrzyczyńska J. Zbiorowiska roślinne Podlaskiego Przełomu Bugu. Cz. II. Zbiorowiska zbożowe. / Plant communities of the cultivated fields of the Podlaski Przełom Bugu mesoregion. Part 2. Cereal communities. Acta Agrobot. 2006; 59(2): 377-391. http://dx.doi. org/10.5586/aa.2006.091 (in Polish)

\section{Różnorodność gatunkowa zbiorowisk segetalnych w uprawach okopowych, zbóż ozimych i jarych}

\section{Streszczenie}

W pracy przedstawiono wyniki badań dotyczących zróżnicowania zbiorowisk zachwaszczających uprawy okopowych, zbóż ozimych i jarych w zbliżonych warunkach klimatycznych i glebowych. Określono ogólne bogactwo gatunkowe w analizowanych grupach upraw, średnią liczbę gatunków w zdjęciu oraz pokrycie badanej powierzchni przez chwasty. $\mathrm{Na}$ powierzchni $1 \mathrm{~m}^{2}$ zbadano skład gatunkowy i liczebność poszczególnych gatunków oraz ich biomasę. Wyróżniono gatunki dominujące w poszczególnych uprawach. Różnorodność gatunkową określono przy użyciu wskaźników ekologicznych: indeksu bioróżnorodności Shannona-Wienera $H^{\prime}$ i dominacji Simpsona $C$. Wskaźniki te liczono w oparciu o biomase i liczebność poszczególnych gatunków. Celem pracy było porównanie struktury i różnorodności zbiorowisk zachwaszczających badane grupy upraw. Analizowane zbiorowiska różniły się pod względem wszystkich badanych cech. Stwierdzono różnice w grupie gatunków dominujących w zachwaszczeniu analizowanych grup 
upraw. Jedynie Setaria pumila, Viola arvensis i Matricaria maritima subsp. inodora miały duże pokrycie we wszystkich badanych uprawach. Najbardziej bogate florystycznie i najbardziej stabilne zbiorowiska noto- wano w zasiewach zbóż ozimych. Stwierdzono różnice wielkości wyliczonych wskaźników bioróżnorodności i dominacji dla badanych grup upraw, jednak ich istotność zależała od zastosowanej metody ich liczenia.

Handling Editor: Elżbieta Weryszko-Chmielewska

This is an Open Access digital version of the article distributed under the terms of the Creative Commons Attribution 3.0 License (creativecommons.org/licenses/by/3.0/), which permits redistribution, commercial and non-commercial, provided that the article is properly cited.

CThe Author(s) 2013 Published by Polish Botanical Society 